\title{
EFEKTIVITAS PEMBELAJARAN MATEMATIKA MENGGUNAKAN MEDIA STATISTIC BALL DENGAN MODEL INQUIRY
}

\author{
Dewi Herawati ${ }^{1}$, Shoffan Shoffa ${ }^{2}$, Achmad Hidayatullah ${ }^{3}$ \\ ${ }^{1,2,3}$ Program studi Pendidikan Matematika, Universitas Muhammadiyah Surabaya, \\ Email: ${ }^{1}$ dewihera47@gmail.com, ${ }^{2}$ shoffanshoffa@gmail.com, ${ }^{3}$ achmadhidayatullah08@gmail.com
}

\begin{abstract}
ABSTRAK
Penelitian ini berawal dari rendahnya hasil belajar siswa, karena dalam proses pembelajaran matematika siswa tidak dilibatkan secara aktif dan proses pembelajaran lebih berfokus pada guru (teacher centered), sehingga guru lebih mendominasi dan menjadi pusat perhatian dalam kegiatan pembelajaran. Hal ini membuktikan kurang efektifnya proses pembelajaran di sekolah. Tujuan dari penelitian ini yaitu untuk melihat efektivitas pembelajaran matematika menggunakan media statistic ball dengan model inquiry pada pembelajaran matematika kelas VIII SMP khusus materi statistika. Jenis penelitian ini adalah penelitian deskriptif kuantitatif. Desain penelitian yang digunakan adalah one group pretest posttest design. Sampel penelitian adalah 30 siswa kelas VIII-C SMP Muhammadiyah 15 Surabaya. Data penelitian berupa observasi untuk mengetahui aktivitas siswa dan kemampuan guru dalam mengelola pembelajaran, angket untuk mengetahui respon siswa, dan soal tes berupa essai untuk mengukur kemampuan matematika pada materi statistika. Hasil penelitian menunjukkan bahwa: kemampuan guru dalam mengelola pembelajaran mendapatkan kategori sangat baik, aktivitas siswa mendapatkan kriteria sangat aktif, ketuntasan hasil belajar siswa menunjukkan $80 \%$ dari semua siswa mencapai KKM, Respon siswa terhadap pembelajaran matematika siswa menunjukkan respon positif. Sehingga penerapan model pembelajaran matematika menggunakan media statistic ball dengan model inquiry efektif digunakan dalam pembelajaran matematika pada siswa kelas VIII-C di SMP Muhammadiyah 15 Surabaya.
\end{abstract}

Kata Kunci: Efektivitas, Pembelajaran Matematika, Media Statistic Ball, Model Inquiry

\begin{abstract}
This research begins from the low student's learning result, because in the mathematic's learning process students aren't actively involved and learning process more focus to teacher (teacher centered), so teacher more dominates and becomes the center of attention in learning activity. This proves that less effective learning process at school. The purpose of this research is looking for the effectivity of mathematics learning using statistic ball media with inquiry model at mathematics learning VIII class junior high school spesifically for statistic lesson. Type of this research is descriptive quantity research. Research design used one group pretest posttest design. Research sample is 30 students class VIII-C Muhammadiyah 15 Junior High School, Surabaya. Research data is observation to find out students activities and teachers ability to manage learning, questionnaire to find out student's response, and test question in the form of essay for measure mathematic ability on statistic learning. The result of this research shows that teacher's ability on manage learning get a very good category, student's activity get a very active criteria, completeness of student's learning result shows that $80 \%$ from all students reach KKM. Student's response to this mathematics learning, students show a positive response. So, application of mathematic learning models used statistic ball media with inquiry model effective use on mathematic learning at student grade VIII-C Muhammadiyah 15 Junior High School, Surabaya.
\end{abstract}

Keywords: Effectivity, Mathematics Learning, Statistic Ball Media, Inquiry Model 


\section{PENDAHULUAN}

Pendidikan adalah usaha sadar untuk menumbuh kembangkan potensi sumber daya manusia. Pendidikan merupakan satu-satunya cara agar manusia dapat menjadi lebih baik dalam meningkatkan sumber daya manusia, sehingga dapat mengimbangi setiap perkembangan yang terjadi agar tidak tertinggal jauh oleh kemajuan (Siagian \& Nurfitriyanti, n.d.). Sesuai dengan Lampiran IV Permendikbud No. 81A Tahun 2013 tentang Pedoman Umum Pembelajaran, dalam kegiatan pembelajaran perlu menggunakan prinsip yang: (1) berpusat pada peserta didik. (2) mengembangkan kreativitas peserta didik, (3) menciptakan kondisi menyenangkan dan menantang, (4) bermuatan nilai, etika, estetika, logika, dan kinestetika, dan (5) menyediakan pengalaman belajar yang beragam melalui penerapan berbagai strategi dan metode pembelajaran yang menyenangkan, kontekstual, efektif, efisien, dan bermakna. Maka semua mata pelajaran yang diajarkan guru harus mencakup kelima prinsip tersebut, termasuk mata pelajaran matematika.

Dalam proses pendidikan formal banyak mata pelajaran yang diajarkan salah satunya adalah matematika. Matematika adalah ilmu yang berhubungan dengan bentuk atau struktur yang bertujuan untuk mempelajari bilangan atau simbol-simbol yang benar-benar menyatu dalam kehidupan seharihari dan membutuhkan setiap manusia untuk berinteraksi dan dapat memahami struktur serta hubungan-hubungannya, diperlukan penguasaan tentang konsep-konsep yang terdapat dalam matematika (Triantnasari, 2017). Matematika merupakan suatu ilmu yang mendukung penguasaan ilmu pengetahuan dan teknologi (Yuliana, 2017). Menurut Hidayatullah (2018), pembelajaran matematika adalah proses mental dari seseorang untuk memahami fakta, keterampilan dan konsep matematika. Indikator seseorang mempelajari matematika dapat dilihat dari perubahan yang terdiri dari kemampuan kognitif, afektif, dan psikomotorik (Hidayatullah, 2018). Pembelajaran matematika yang benar sangat diperlukan dalam menanamkan konsep-konsep matematika di sekolah (Triantnasari, 2017).

Kenyataan yang selama ini terjadi dalam proses pembelajaran matematika adalah sebagian besar siswa berpandangan bahwa mata pelajaran matematika merupakan mata pelajaran yang membosankan dan menakutkan. Hal ini disebabkan karena dalam proses pembelajaran matematika siswa tidak dilibatkan secara aktif dan proses pembelajaran lebih berfokus kepada guru (teacher centered) sehingga, guru lebih mendominasi dan menjadi pusat perhatian dalam kegiatan pembelajaran. Dengan pembelajaran tersebut siswa tidak diberikan kesempatan untuk mengembangkan ide dan menemukan alternatif pemecahan masalah, tetapi siswa bergantung pada guru (Shoffa, 2009).

Oleh karena itu hasil belajar yang kurang efektif tersebut perlu ditingkatkan dengan menggunakan model pembelajaran dan di dukung dengan media yang inovatif. Agar siswa dapat berpartisipasi aktif dan mendapatkan hasil belajar yang lebih baik. Salah satu model pembelajaran yang mampu untuk meningkatkan pemahaman pada pembelajaran matematika adalah model pembelajaran inquiry. Menurut Hasan (2014) model pembelajaran inquiry yaitu suatu proses untuk memperoleh dan mendapatkan informasi dengan melakukan observasi untuk mencari jawaban atau memecahkan masalah terhadap pertanyaan atau rumusan masalah dengan menggunakan kemampuan berpikir kritis dan logis. Belajar dengan menggunakan model inquiry diharapkan siswa menjadi lebih kreatif, inovatif dan belajar lebih bermakna (Mustachfidoh \& Manikwidyantini, 2013). Menurut Susanto (2013) inquiry merupakan proses yang bervariasi dan meliputi kegiatan-kegiatan mengobservasi, merumuskan pertanyaan yang relevan, mengevaluasi buku dan sumber-sumber informasi lain secara kritis, merencanakan penyelidikan atau investigasi, me-review apa yang telah diketahui, melaksanakan percobaan atau eksperimen dengan menggunakan alat untuk memperoleh data, menganalisis dan menginterpretasi data, serta membuat prediksi dan mengkomunikasikan hasilnya. Menurut Khoik, Holisin, \& Kristanti (2016) inquiry adalah rangkaian kegiatan pembelajaran yang menekankan pada proses berfikir secara kritis dan analitis untuk menemukan suatu jawaban.

Berdasarkan hasil penelitian Zuhdan Ulil Abshor tahun 2016 menyimpulkan bahwa bahwa ratarata hasil belajar matematika peserta didik yang diajar dengan model pembelajaran inquiry berbantu alat peraga Basic Statistic Counter lebih tinggi dari rata-rata hasil belajar peserta didik yang diajar dengan pembelajaran sesuai kurikulum yang berlaku tanpa model inquiry dan alat peraga pada materi 
statistika. Berdasarkan data yang diperoleh, rata-rata hasil belajar peserta didik kelas eksperimen adalah 77,54 sedangkan rata-rata hasil belajar kelas kontrol adalah 68,25. Hasil penelitian tentang model pembelajaran inquiry di atas, peneliti menyimpulkan bahwa model pembelajaran inquiry merupakan salah satu alternatif belajar untuk meningkatkan keaktifan dan hasil belajar siswa pada mata pelajaran matematika. Model pembelajaran inquiry cocok untuk diterapkan dalam pembelajaran matematika. Hal ini karena model pembelajaran inquiry lebih menekankan pada keaktifan serta kemampuan berpikir kreatif siswa dan siswa tidak mengalami kesulitan ketika menghadapi masalah dalam pembelajaran.

Dalam penelitian ini, peneliti memfokuskan pada materi statistika, dimana peserta didik dituntut untuk memahami konsep. Statistika merupakan salah satu aspek dalam mata pelajaran matematika yang harus diberikan kepada siswa sejak sekolah dasar (kelas 6) dan selanjutnya diperdalam lagi di SMP/MTs. Kendala yang masih banyak dirasakan oleh para guru dalam mengajar bab statistika antara lain yang berkaitan dengan penyajian data, serta kendala bagi guru itu sendiri yaitu dalam hal penyampaian materi sehingga dibutuhkan media pembelajaran agar mempermudah guru dalam meyampaikan materi statistika. (Widyantini, 2008)

Media pembelajaran adalah alat perantara untuk menyampaikan sebuah informasi maupun pesan dari sumber informasi kepada orang lain. Media pendidikan merupakan alat bantu atau pelengkap yang digunakan oleh guru atau pendidik dalam berkomunikasi dengan siswa (Lenggono, 2017). Media pembelajaran juga dibutuhkan ketika proses pembelajaran berlangsung, karena belajar yang efektif harus bermula dengan pengalaman langsung atau konkret kemudian menuju kepada pengalaman yang lebih abstrak. Selain itu, media pembelajaran dapat berperan sebagai alat bantu untuk menciptakan suasana belajar yang efektif dan efisien. Tujuan nya melalui media pembelajaran tersebut, diharapkan peserta didik dapat mengkonstruksi pengetahuan baru dengan mengorganisir, menginterpretasi, menghubungkan pengertian-pengertian yang dipahami sendiri dengan bantuan media pembelajaran sehingga konsep yang dipahami tidak cepat hilang serta menjadi pembelajaran yang bermakna. Agar komunikasi dan interaksi dengan siswa dapat terjalin dengan baik maka guru harus memperhatikan kesiapan intelektual siswa serta pemilihan model dan penggunaan media pembelajaran yang tepat dalam proses pembelajaran. Dengan menggunakan model dan media pembelajaran diharapkan dapat mempermudah peserta didik untuk menerima dan memahami konsep matematika (Herawati, 2017).

Untuk mengatasi permasalahan tersebut peneliti menggunakan model pembelajaran inquiry berbantu media pembelajaran "Statistic Ball" dalam materi statistika. Berdasarkan uraian di atas peneliti merasa tertarik dan ingin melakukan penelitian dengan judul "Efektivitas Pembelajaran Matematika Menggunakan Media Statistic Ball dengan Model Inquiry Pada Kelas VIII SMP Muhammadiyah 15 Surabaya".

Adapun tujuan penelitian ini adalah: (1) mendeskripsikan ketuntasan hasil belajar siswa pada pembelajaran matematika menggunakan media statistic ball dengan model inquiry, (2) mendeskripsikan aktivitas siswa pada pembelajaran matematika menggunakan media statistic ball dengan model inquiry, (3) mendeskripsikan kemampuan guru mengajar siswa, (4) mendeskripsikan respon siswa pada pembelajaran matematika menggunakan media statistic ball dengan model inquiry.

\section{METODE}

Jenis penelitian yang dilakukan adalah penelitian eksperimental. Karena penelitian ini hanya mendeskripsikan kemampuan guru dalam mengelola pembelajaran, aktivitas siswa pada saat pembelajaran, ketuntasan belajar yang diperoleh siswa setelah mengikuti pembelajaran, dan respon siswa terhadap media Statistic Ball dengan model Inquiry. Pada penelitian ini terdapat 2 variabel yaitu variabel bebas dan variabel terikat. Sebagai variabel bebas yaitu pembelajaran matematika menggunakan media statistic ball dengan model inquiry. Adapun variabel terikat yaitu efektivitas pembelajaran yang terdiri dari kemampuan guru dalam mengelola pembelajaran, aktivitas siswa, ketuntasan hasil belajar, dan respon siswa. Kelompok kelas eksperimen mendapatkan perlakuan pembelajaran menggunakan media statistic ball dengan model inquiry. Desain penelitian yang digunakan dalam penelitian ini adalah one group pretest posttest design. Dalam desain ini, sebelum diberikan perlakuan terlebih dahulu sampel diberi pretest (tes awal) dan di akhir pembelajaran sampel diberi posttest (tes akhir). Adapun desain penelitian yang digunakan dalam penelitian ini adalah: 


\section{$O_{1} \mathrm{X} \mathrm{O}_{2}$}

(Sugiyono, 2014)

Keterangan:

$O_{1}$ : tes awal sebelum perlakuan diberikan

$\mathrm{O}_{2}$ : tes akhir setelah perlakuan diberikan

$X$ : perlakuan terhadap kelompok penelitian yaitu dengan menerapkan media Statistic Ball dengan model Inquiry

Tempat penelitian tentang efektivitas pembelajaran matematika menggunakan media statistic ball dengan model inquiry dilaksanakan di SMP Muhammadiyah 15 Surabaya di Jl. Platuk No.104, Sidotopo Wetan, Kenjeran, Surabaya. Waktu penelitian dilakukan pada semester genap tahun ajaran 2018/2019 yang berlangsung pada bulan Maret 2019. Pengumpulan data menggunakan instrumen lembar validasi, lembar observasi aktivitas siswa, lembar observasi kemampuan guru dalam mengelola pembelajaran, soal pretest dan posttest, dan angket respon siswa.

Penelitian diawali dengan pretest yang dilaksanakan di kelas uji coba sebagai instrumen soal. Dari hasil uji coba di analisis untuk mengetahui soal mana yang layak dipakai untuk soal pretest kelas eksperimen. Proses uji coba instrumen menggunakan SPSS versi 24 for windows. Analisis yang digunakan untuk menguji instrumen yaitu: validitas soal, reliabilitas soal. Setelah soal dianalisis kemudian ditentukan soal mana yang layak digunakan di kelas eksperimen. Selanjutnya pada pertemuan pertama dilaksanakan pretest di kelas eksperimen untuk mengetahui hasil belajar siswa sebelum diberikan perlakuan, pada pertemuan kedua dan ketiga dilaksanakan proses pembelajaran matematika menggunakan media statistic ball dengan model inquiry, pada pertemuan keempat siswa diberi soal posttest untuk mengetahui hasil belajar siswa setelah diberi perlakuan dan pemberian angket respon siswa untuk mengetahui respon siswa setelah diberikan pembelajaran matematika menggunakan media statistic ball dengan model inquiry. Uji prasyarat dalam penelitian ini yaitu uji homogenitas, dan uji hipotesis menggunakan uji t-berpasangan.

\section{HASIL}

Sebelum mendeskripsikan data hasil penelitian, terlebih dulu dilakukan validasi secara teoritis oleh dosen dan guru matematika. Validasi secara teoritis digunakan untuk mengetahui validitas (ketepatan/ kelayakan) suatu perangkat pembelajaran dan instrumen penelitian.

Perangkat pembelajaran yang divalidasi oleh ahli meliputi: Lembar Kegiatan Siswa (LKS), Rencana Pelaksanaan Pembelajaran (RPP), media statistic ball, soal pretest dan soal posttest. Dan instrumen penelitian yang meliputi: lembar observasi aktivitas siswa, lembar observasi kemampuan guru dalam mengelola pembelajaran dan angket respon siswa. Ahli yang memvalidasi perangkat yang akan digunakan untuk pembelajaran ditunjukkan pada tabel 1.

Tabel 1. Validator Perangkat Pembelajaran

\begin{tabular}{cc}
\hline Validator & Nama \\
\hline I & Endang Suprapti, S.Pd, M.Pd. \\
\hline II & Fitri Miftahul Jannah, S.Pd \\
\hline
\end{tabular}

Berikut hasil validasi perangkat pembelajaran dan instrumen yang digunakan untuk penelitian yaitu sebagai berikut:

Tabel 2. Hasil Validasi Perangkat Pembelajaran

\begin{tabular}{lcccc}
\hline \multirow{2}{*}{ Perangkat Pembelajaran } & \multicolumn{2}{c}{ Validator } & \multirow{2}{*}{ Rata-rata } & \multirow{2}{*}{ Kategori } \\
\cline { 2 - 3 } & I & II & & \\
\hline Lembar Kerja Siswa (LKS) & 3,78 & 4 & 3,89 & Valid \\
\hline Rencana Pelaksanaan Pembelajaran & 3.89 & 3,89 & 3,89 & Valid \\
\hline
\end{tabular}




\begin{tabular}{lcccc}
\hline \multirow{2}{*}{ Perangkat Pembelajaran } & \multicolumn{2}{c}{ Validator } & \multirow{2}{*}{ Rata-rata } & \multirow{2}{*}{ Kategori } \\
\cline { 2 - 3 } & I & II & & \\
\hline (RPP) & & & & \\
\hline Soal Pretest dan Posttest & 3,78 & 4 & 3,875 & Valid \\
\hline Media Statistic Ball & 3,85 & 4 & 3,925 & Valid \\
\hline Lembar Observasi Aktivitas Siswa & 3,71 & 4 & 3,855 & Valid \\
\hline $\begin{array}{l}\text { Lembar Observasi Kemampuan guru } \\
\text { dalam mengelola pembelajaran }\end{array}$ & 3,89 & 4 & 3,945 & Valid \\
\hline Angket respon siswa & 3,6 & 3,7 & 3,65 & Valid \\
\hline
\end{tabular}

Perangkat pembelajaran sudah divalidasi oleh dua validator dan dinyatakan valid, sehingga perangkat pembelajaran dapat digunakan untuk penelitian.

Uji prasyarat analisis data yaitu uji homogenitas. Pengujian homogenitas ini dilakukan melalui ujiF dengan $\alpha=0.05$ dan disimpulkan data bersifat homogen atau memiliki varians yang sama. Pengujian hipotesis penelitian ini dilakukan dengan Uji-F yang dapat dilihat pada tabel berikut ini:

Tabel 3. Hasil Perhitungan Uji Homogenitas

\begin{tabular}{|c|c|c|c|c|c|}
\hline & & $\begin{array}{l}\text { Levene } \\
\text { Statistic }\end{array}$ & df1 & df2 & Sig. \\
\hline \multirow[t]{4}{*}{ Hasil_Pretest } & $\begin{array}{l}\text { Based on } \\
\text { Mean }\end{array}$ & 0.859 & 1 & 58 & 0.358 \\
\hline & $\begin{array}{l}\text { Based on } \\
\text { Median }\end{array}$ & 0.540 & 1 & 58 & 0.465 \\
\hline & $\begin{array}{l}\text { Based on } \\
\text { Median } \\
\text { and with } \\
\text { adjusted df }\end{array}$ & 0.540 & 1 & 51.634 & 0.466 \\
\hline & $\begin{array}{l}\text { Based on } \\
\text { trimmed } \\
\text { mean }\end{array}$ & 0.820 & 1 & 58 & 0.369 \\
\hline
\end{tabular}

Berdasarkan hasil dari tabel $1 \mathrm{di}$ atas, diperoleh signifikan 0,358. Karena nilai signifikan nya lebih dari 0,05 maka kelas VIII-A dan kelas VIII-C bersifat homogen atau memiliki varians yang sama. Pada pengujian lanjutan digunakan Uji-t dilakukan untuk menguji apakah terjadi peningkatan kemampuan yang signifikan antara sebelum dan sesudah pembelajaran statistika menggunakan media statistic ball dengan model inquiry. Berdasarkan hasil perhitungan menggunakan SPSS 24 for windows diperoleh output sebagai berikut:

Tabel 4. Hasil Perhitungan Uji-t

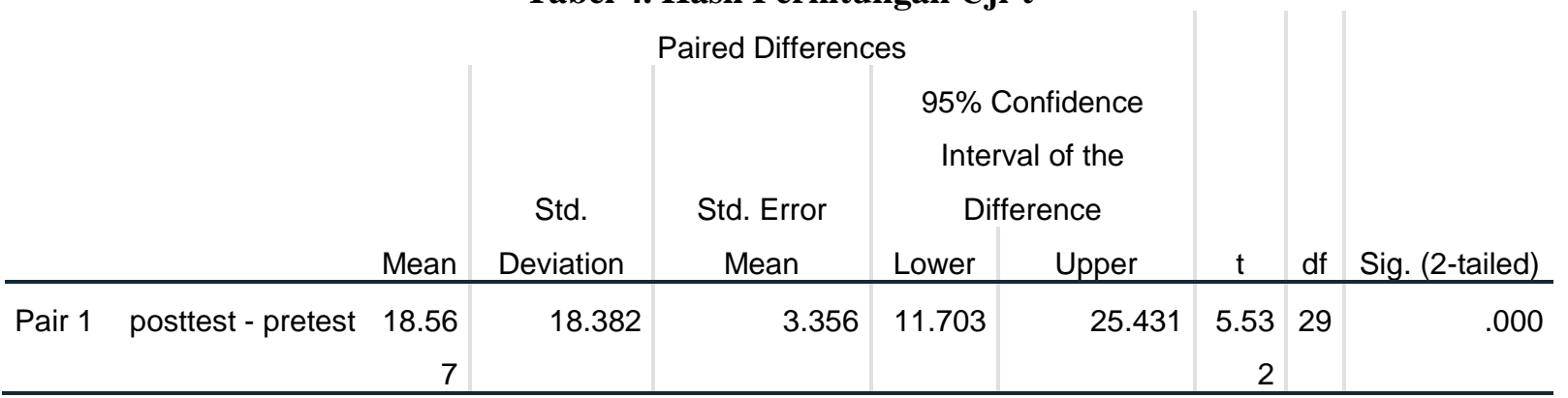


Nilai t-hitung adalah sebesar 5,532 dengan sig 0,000. Karena sig $<0,05$ maka dapat disimpulkan bahwa $H_{0}$ ditolak dan $H_{1}$ diterima, yang artinya rata-rata pre-test dan post-test adalah berbeda. Dengan demikian dapat dinyatakan bahwa pembelajaran mempengaruhi nilai pre-test dan post-test. Kesimpulan $H_{0}$ ditolak dan $H_{1}$ diterima artinya pre-test dan post-test ada perbedaan signifikan. Pada output perbedaan mean 18,567 yaitu selisih antara pre-test dan post-test.

\section{PEMBAHASAN}

Hasil dari analisis data yang sudah diperoleh kemudian diuraikan untuk mengetahui efektivitas pembelajaran matematika menggunakan media statistic ball dengan model inquiry pada kelas VIII SMP Muhammadiyah 15 Surabaya. Untuk mengetahui efektivitas pembelajaran ada empat aspek yang diteliti, antara lain kemampuan guru dalam mengelola pembelajaran, aktivitas siswa, ketuntasan hasil belajar siswa, dan respon siswa. Kemampuan guru dalam mengelola pembelajaran dilaksanakan pada 2 pertemuan, yaitu pada tanggal 19 maret 2019 dan 21 maret 2019. Berikut disajikan pembahasan mengenai kemampuan guru dalam mengelola pembelajaran, aktivitas siswa, ketuntasan hasil belajar siswa, dan respon siswa.

Observasi terhadap kemampuan guru dalam mengelola pembelajaran di kelas VIII-C. pengambilan data kemampuan guru dalam mengelola pembelajaran dilakukan dengan memberi tanda cek $(\sqrt{ })$ pada lembar observasi yang diisi oleh observer. Pelaksanaan aspek kegiatan pendahuluan meliputi salam pembuka serta berdoa mendapatkan rata-rata 4 dengan kriteria sangat baik, memeriksa kehadiran siswa mendapatkan rata-rata 4 dengan kriteria sangat baik, memberikan apersepsi tentang materi sebelumnya mendapatkan rata-rata 3,5 dengan kriteria sangat baik, menginformasikan materi yang akan dipelajari mendapatkan rata-rata 3,5 dengan kriteria sangat baik dan menyampaikan tujuan pembelajaran mendapatkan rata-rata 3,5 dengan kriteria sangat baik. Pelaksanaan aspek kegiatan inti yang meliputi membagi siswa ke dalam beberapa kelompok mendapatkan rata-rata 4 dengan kriteria sangat baik, membagikan LKS pada masing-masing kelompok mendapatkan rata-rata 4 dengan kriteria sangat baik, memberikan petunjuk penggunaan statistic ball dan meminta siswa membaca LKS bagian orientasi dan merumuskan masalah mendapatkan rata-rata 3,5 dengan kriteria sangat baik, meminta siswa membuat hipotesis dan meminta siswa mengumpulkan data pada LKS dengan bimbingan guru mendapatkan rata-rata 3 dengan kriteria baik, selanjutnya guru meminta siswa menuliskan hasil hipotesis dan guru memberikan umpan balik berupa penjelasan tentang apa saja yang ditemukan siswa pada LKS mendapatkan rata-rata 3,5 dengan kriteria sangat baik. Pada kegiatan penutup yang meliputi meminta siswa menuliskan kesimpulan dan membimbing siswa dalam membuat kesimpulan mendapatkan rata-rata 4 dengan kriteria sangat baik, menutup pembelajaran dengan mengucapkan salam mendapatkan rata-rata 3 dengan kriteria baik. Berdasarkan hasil pengamatan kemampuan guru dalam mengelola pembelajaran sesuai dengan RPP selama dua kali pertemuan mendapatkan rata-rata total 3,625. Dengan demikian, kemampuan guru dalam mengelola pembelajaran termasuk dalam kategori sangat baik. Sebagaimana menurut (Sudjana, 2002) kemampuan dasar yang harus dimiliki seorang guru berupa pengetahuan, keterampilan, sikap, dan nilai-nilai yang diperoleh sehingga dapat melaksanakan tugasnya dengan baik. Sehingga dapat disimpulkan bahwa kemampuan guru dalam mengelola pembelajaran dengan menggunakan media statistic ball dengan model inquiry pada materi statistika di kelas VIII-C termasuk dalam kriteria sangat baik.

Observasi terhadap aktivitas siswa dilakukan selama dua pertemuan dalam proses pembelajaran matematika menggunakan media statistic ball dengan model inquiry. Aktivitas siswa dikelompokkan ke dalam sepuluh kategori. Subjek dalam penelitian ini adalah siswa kelas VIII-C SMP Muhammadiyah 15 Surabaya yang terdiri dari 6 kelompok yang masing-masing terdiri dari 5 orang. Observasi aktivitas siswa dilakukan oleh 3 observer yang masing-masing mengamati 2 kelompok. Aktivitas siswa diperoleh berdasarkan hasil pengamatan yang dicatat 5 menit sekali dalam tiap pertemuan. Aktivitas yang paling banyak dilakukan siswa setelah dirata-rata adalah "siswa melaksanakan diskusi kelompok sesuai dengan petunjuk guru". Hal ini dikarenakan antusias siswa selama mengikuti pembelajaran matematika mengunakan media statistic ball dengan model inquiry. Siswa sangat antusias pada saat berdiskusi mengerjakan LKS. Aktivitas siswa yang paling sedikit dilakukan adalah "siswa bertanya kepada guru apabila mengalami kesulitan". Hal ini dikarenakan guru sudah memberi petunjuk cara mengerjakan LKS dan hanya beberapa kali membimbing siswa 
yang mengalami kesulitan, agar siswa dapat menemukan konsep tentang pembelajaran statistika menurut apa yang sudah ditemukan pada LKS. Secara keseluruhan, aktivitas siswa selama pembelajaran matematika menggunakan media statistic ball dengan model inquiry di kelas VIII-C di SMP Muhammadiyah 15 Surabaya mendapatkan rata-rata persentase aktivitas siswa secara keseluruhan sebesar 100\%. Karena presentase total 100\%, maka dapat dikatakan bahwa siswa tergolong sangat aktif. Sebagaimana menurut (Sudjana, 2009: 61) keaktifan siswa dapat dilihat dari: (1) turut serta dalam melaksanakan tugas belajarnya, (2) terlibat dalam pemecahan masalah, (3) bertanya kepada siswa lain atau guru apabila mengalami kesulitan, (4) berusaha mencari berbagai informasi yang diperlukan untuk memecahkan masalah, (5) melaksanakan diskusi kelompok sesuai dengan petunjuk guru, (6) menilai kemampuan dirinya, (7) melatih diri dalam memecahkan soal, (8) menerapkan apa yang diperoleh dalam menyelesaikan tugas.

Menurut Bloom dalam (Suprijono, 2009: 6) hasil belajar mencakup kemampuan kognitif, afektif, dan psikomotorik. Hasil belajar siswa dalam penelitian ini memperhatikan penilaian dalam ranah kognitif atau pengetahuan. Menurut Abdurrahman dalam (Jihad \& Haris, 2008: 14) hasil belajar adalah kemampuan yang diperoleh siswa setelah melalui kegiatan belajar. Siswa dikatakan berhasil dalam belajar apabila siswa dapat mencapai tujuan belajar. Dalam penelitian ini, tes hasil belajar dilakukan sebelum pembelajaran (pretest) dan sesudah pembelajaran (posttest). Pretest dilakukan sebelum pembelajaran menggunakan media statistic ball dengan model inquiry berlangsung. Pretest dilaksanakan pada tanggal 18 Maret 2019. Pretest terdiri dari 5 soal yang masing-masing soal uraian dan pengerjaan soal dalam waktu 40 menit. Sedangkan posttest dilaksanakan pada tanggal 25 Maret 2019. Posttest terdiri dari 5 soal yang masing-masing soal uraian dan pengerjaan soal dalam waktu 40 menit. Pretest dan posttest dikerjakan secara individu tidak boleh saling bekerja sama agar hasil pretest dan posttest yang diperoleh benar-benar menggambarkan kemampuan setiap siswa. Dalam penelitian ini, peneliti memberikan pretest dan posttest kepada kelas VIII-C yang berjumlah 30 siswa. Berdasarkan hasil pretest dapat dilihat bahwa nilai pretest 12 siswa atau $40 \%$ dari jumlah siswa tuntas belajar, sedangkan 18 siswa atau 60\% dari jumlah siswa belum tuntas belajar. Sedangkan hasil posttest siswa setelah dilaksanakan pembelajaran matematika menggunakan media statistic ball dengan model inquiry pada materi statistika menunjukkan bahwa 24 siswa atau $80 \%$ siswa tuntas belajar sedangkan 6 siswa atau 20\% dari jumlah siswa belum tuntas belajar. Dengan rata-rata 82,7 dan simpangan baku 12,05. Ketuntasan hasil belajar di atas dikarenakan pembelajaran matematika menggunakan media statistic ball dengan model inquiry, sehingga membuat siswa tuntas belajar dalam penguasaan materi statistika, karena ketuntasan hasil belajar di kelas lebih dari $75 \%$.

Respon siswa diberikan setelah melaksanakan pembelajaran matematika menggunakan media statistic ball dengan model inquiry pada materi statistika. Siswa diminta mengisi angket untuk mengetahui ketertarikan siswa terhadap pembelajaran matematika menggunakan media statistic ball dengan model inquiry. Subjek dalam penelitian ini yaitu seluruh siswa kelas VIII-C yang berjumlah 30 siswa. Pertanyaan angket respon siswa ini terdiri dari 7 pernyataan yang berhubungan dengan pembelajaran matematika menggunakan media statistic ball dengan model inquiry. Kategori respon positif di dapatkan jika siswa memilih SS (Sangat Setuju) atau S (Setuju) pada setiap pernyataan, sedangkan kategori respon negatif di dadapatkan jika siswa memilih TS (Tidak Setuju) atau STS (Sangat Tidak Setuju) pada setiap pernyataan. Berdasarkan hasil angket respon siswa dapat disimpulkan bahwa rata-rata total respon positif sebesar $96 \%$ dan rata-rata total respon negatif sebesar 4\%. Sehingga dapat disimpulkan bahwa pembelajaran matematika menggunakan media Statistic Ball dengan model Inquiry dalam kategori sangat positif. Sebagaimana menurut (Ahmadi, 1999: 166) respon positif merupakan sebuah bentuk respon, tindakan, atau sikap yang menunjukkan atau memperlihatkan, menerima, mengakui, menyetujui, serta melaksanakan norma-norma yang berlaku dimana individu itu berada.

\section{SIMPULAN DAN SARAN}

Berdasarkan hasil pengujian hipotesis, dapat disimpulkan bahwa pembelajaran matematika melalui media statistic ball dengan model inquiry efektif digunakan dalam pembelajaran matematika. Seluruh aktivitas guru yang dilakukan untuk mengetahui kemampuan guru dalam mengelola pembelajaran dari pertemuan pertama hingga pertemuan kedua di dapatkan rata-rata keseluruhan yaitu 3,625 dengan kategori sangat baik. Aktivitas siswa selama mengikuti pembelajaran matematika 
menggunakan media statistic ball dengan model inquiry termasuk dalam kriteria sangat aktif karena rata-rata persentase aktivitas siswa sebesar $100 \%$. Banyak siswa yang hasil belajarnya mencapai KKM setelah mengikuti pembelajaran menggunakan media statistic ball dengan model inquiry pada materi statistika di kelas VIII-C yaitu sebanyak $80 \%$. Respon siswa setelah mengikuti pembelajaran matematika menggunakan media statistic ball dengan model inquiry yaitu masuk dalam kategori sangat positif yaitu sebesar $96 \%$.

Berdasarkan paparan data dan pembahasan, peneliti menyarankan bahwa media statistic ball dengan model inquiry dapat digunakan sebagai salah satu alternatif dalam pembelajaran matematika khususnya materi statistika, peneliti juga memberikan rekomendasi kepada peneliti lain untuk mengunakan media statistic ball dengan model-model pembelajaran lain.

\section{DAFTAR RUJUKAN}

Ahmadi. (1999). Psikologi sosial. Jakarta: Rineka Cipta.

Hidayatullah, A. (2018a). Digital Learning. Surabaya: UM Surabaya.

Hidayatullah, A. (2018b). Pembelajaran matematika pada era media sosial dan budaya. Jurnal pendidikan matematika. Diambil dari http://jurnal.pmat.uniba-bpn.ac.id

Jihad, A., \& Haris, A. (2008). Evaluasi pembelajaran. Yogyakarta: Multi Pressindo.

Khoik, A., Holisin, I., \& Kristanti, F. (2016). Peningkatan hasil belajar matematika melalui model pembelajaran guided inquiry pokok bahasan garis singgung lingkaran pada siswa Madrasah Tsanawiyah. MUST:Journal of Mathematics Education, Science and Technology, 1.

Lenggono, W. (2017). Penggunaan media pembelajaran. Purwokerto: UMP.

Shoffa, S. (2009). Pengembangan perangkat pembelajaran matematika dengan pendekatan PMR pada pokok bahasan jajargenjang dan belah ketupat. Didaktis, 8, 43-44.

Sudjana, N. (2002). Dasar-dasar proses belajar mengajar. Bandung: Sinar Baru Algesindo.

Sudjana, N. (2009). Dasar-dasar proses belajar mengajar. Bandung: PT Remaja Rosdakarya.

Sugiyono. (2014). Metode penelitian kualitatif, kuantitatif, dan R\&D. Bandung: Alfabeta.

Suprijono, A. (2009). Cooperative Learning. Yogyakarta: Pustaka Belajar.

Susanto, A. (2013). Teori belajar dan pembelajaran di Sekolah Dasar. Jakarta: Prenada Media Group.

Triantnasari, V. (2017). Penggunaan metode bernyanyi dalam meningkatkan hasil belajar siswa pada pembelajaran matematika kelas III-B. Lampung: Institut Agama Islam Negeri Raden Intan Lampung.

Yuliana, M., Suryaningtyas, W., \& Shoffa, S. (2017). Pengaruh model pembelajaran kooperatif tipe STAD dengan metode mnemonik terhadap hasil belajar siswa kelas X di SMA Muhammadiyah 1 Surabaya. MUST:Journal of Mathematics Education, Science and Technology, 2, 143. 